\title{
Successful Treatment of Neonatal Herpes Simplex Infec- tion Presenting as Fulminant Hepatitis with Acyclovir and Peritoneal Dialysis
}

\author{
Seonghye Choi, MD, Jang Hoon Lee, MD, and Moon Sung Park, MD \\ Department of Pediatrics, Ajou University Hospital, Ajou University School of Medicine, Suwon, Korea
}

\section{ABSTRACT}

Disseminated neonatal herpes simplex virus (HSV) infection is a severe disease with a high mortality rate. Here, we report the patient presented with fulminant hepatic failure secondary to HSV infection followed by renal failure without any mucocutaneous symptoms. The patient recovered after treatment with acyclovir and peritoneal dialysis. This is the first known case of a patient in Korea who survived disseminated HSV infection with fulminant liver failure followed by renal failure without undergoing liver transplantation.

Key Words: Infant, newborn; Fulminant hepatitis; Liver failure; Herpes simplex

서론

신생아 단순헤르페스 바이러스(herpes simplex virus) 감염은 치료하지 않을 경우 $60 \%$ 정도의 높은 사망률을 보이는 질환으로, 대한민국에서는 100,000 명의 출생아 중 10 명 이내에서 단순헤 르페스 바이러스 감염이 발생한다 ${ }^{1)}$. 단순헤르페스 바이러스 감염은 (1) 폐, 간, 부신을 포함한 여 러 내장 기관을 침범하는 파종감염, (2) 중추신경계 감염, (3) 피부, 눈, 점막에 국학된 질환으로 나뉜달. 단순헤르페스 바이러스 감염을 치료하지 않을 경우 파종감염 환자 중 $85 \%$, 중추신경계 감염 환자 중 $50 \%$ 가 1년 이내에 사망하지만, 고용량 아시클로버(acyclovir)로 치료를 2 일 이내 시작한 경우 파종감염은 사망률이 $31 \%$, 중추신경계 질환은 $6 \%$ 까지 낮아진다 ${ }^{3}$. 그러나 신생아 단순헤르페스 감염의 초기 증상은 대부분 비특이적이고, $40 \%$ 의 환자에서는 피부병변이 없어 진 단이 늦어지게 된다 ${ }^{4}$. 또한 신생아 단순헤르페스 감염의 대부분(85\%)은 분만 중 산도를 통과할 때 감염되는데, 산모의 음부 포진은 증상 및 징후가 없는 경우가 많아 조기 진단을 어렵게 한달.

단순헤르페스 바이러스 감염에 의한 전격성 간부전이 발생한 신생아를 아시클로버만으로 치 료한 사례와 간이식을 시행하여 치료한 사례는 몇 건이 보고된 것이 있으나 전격성 간부전과 신 부전이 발생하여 이식 없이 내과적 치료로 회복된 사례 보고는 없었다,5, . 이에 본 저자들은 단 순헤르페스 바이러스 감염으로 인해, 전격성 간부전과 신부전이 발생한 신생아를 아시클로버와 복막투석을 통해 성공적으로 치료한 1례가 있어 보고한다.
Received: 22 May 2019

Revised: 23 September 2019

Accepted: 25 September 2019

Correspondence to: Jang Hoon Lee, MD

Department of Pediatrics, Ajou University Hospital, Ajou University School of Medicine, 164 World cup-ro, Yeongtong-gu, Suwon 16499, Korea

Tel: +82-31-219-5167

Fax: +82-31-219-5169

E-mail: neopedlee@gmail.com

Copyright(c)

By Korean Society of Neonatology.

All right reserved.

This is an Open-Access article distributed under the terms of the Creative Commons Attribution Non-Commercial License (http://creativecommons.org/licenses/ by-nc/4.0), which permits unrestricted non-commercial use, distribution, and reproduction in any medium, provided the original work is properly cited. 
증례

생후 3 일 된 여아가 내원 당일부터 시작된 발열을 주소로 응급실 에 내원하였다. 환아는 재태 연령 38 주, 출생체중 $3,700 \mathrm{~g}$, 자연분 만으로 개인 산부인과에서 주산기 문제없이 출생하였으며, 아프가 (Apgar) 점수는 1 분 9점, 5 분 10점이었다. 출생 후 조리원에서 지냈 으며 발열 발생 전까지 특이소견은 없었다. 산모는 26세 초산부로 헤르페스를 포함한 감염력 및 과거력은 없던 자로, 출산 시 조기양막 파수는 없었다. 산모는 음부 포진 및 피부병변은 없었으며 3일 전부 터 발열을 동반한 유방 울혈로 해열제를 투여받았다. 환아와 접촉하 였던 사람 중 피부병변이 있는 자는 없었다.

응급실 내원 직후 측정한 환아의 체온은 $38.9^{\circ} \mathrm{C}$ 였으며, 발열 이외 의 증상은 없었다. 신체 진찰상 피부의 수포나 발진을 포함하여 특 이소견은 없었다. 내원 전까지 환아가 투여받은 약제는 없었다. 패 혈증 추정 하에 경험적 항생제로 유박신(ampicillin/sulbactam)을 투 여하기 시작하였다. 내원 직후 시행한 혈액검사는 Table 1 에서와 같

Table 1. Laboratory Findings

\begin{tabular}{|c|c|c|c|c|c|c|}
\hline \multirow{2}{*}{ Variable } & \multicolumn{5}{|c|}{ Days after birth } & \multirow{2}{*}{$\begin{array}{l}\text { Reference } \\
\text { range }\end{array}$} \\
\hline & 3 & 6 & 7 & 8 & 9 & \\
\hline $\begin{array}{l}\text { White blood cells } \\
\left(\times 10^{3} / \mu \mathrm{L}\right)\end{array}$ & 11.4 & 8.3 & 10.4 & 11.4 & 9.6 & $5.0-19.5$ \\
\hline $\begin{array}{l}\text { Red blood cells } \\
\left(\times 10^{6} / \mu \mathrm{L}\right)\end{array}$ & 3.48 & 3.35 & 3.38 & 3.05 & 3.86 & $3.6-6.2$ \\
\hline Hemoglobin (g/dL) & 12.7 & 12.1 & 11.8 & 10.8 & 12.5 & $14.5-22.5$ \\
\hline Hematocrit (\%) & 37.7 & 36.6 & 35.8 & 31.9 & 37.1 & $44-72$ \\
\hline Platelets $\left(\times 10^{3} / \mu \mathrm{L}\right)$ & 192 & 115 & 103 & 83 & 66 & $150-400$ \\
\hline $\mathrm{Na}^{+}(\mathrm{mEq} / \mathrm{L})$ & 143 & 141 & - & 136 & 133 & $136-146$ \\
\hline $\mathrm{K}^{+}(\mathrm{mEq} / \mathrm{L})$ & 4.8 & 4.9 & - & 4.1 & 7.0 & $3.0-7.0$ \\
\hline $\mathrm{Cl}^{-}(\mathrm{mEq} / \mathrm{L})$ & 109 & 110 & - & 107 & 100 & $97-110$ \\
\hline Total $\mathrm{CO}_{2}(\mathrm{mEq} / \mathrm{L})$ & 22 & 20 & - & 20 & 19 & $13-22$ \\
\hline BUN (mg/dL) & 4.3 & - & 5.4 & 26.6 & 55.2 & $3-12$ \\
\hline Creatinine (mg/dL) & 0.6 & - & 0.4 & 1.2 & 2.0 & $0.3-1.0$ \\
\hline $\operatorname{AST}(\mathrm{U} / \mathrm{L})$ & 57 & 1,072 & 2,729 & 6,367 & 4,042 & $17-375$ \\
\hline $\operatorname{ALT}(\mathrm{U} / \mathrm{L})$ & 13 & 163 & 406 & 738 & 500 & $6-50$ \\
\hline Total bilirubin (mg/dL) & - & 6.2 & - & 4.6 & - & $<10$ \\
\hline $\begin{array}{l}\text { Direct bilirubin } \\
(\mathrm{mg} / \mathrm{dL})\end{array}$ & - & 1.5 & - & 4.3 & - & $<1.0$ \\
\hline $\mathrm{CRP}(\mathrm{mg} / \mathrm{dL})$ & 0.47 & 1.34 & 1.59 & 0.96 & 0.88 & $0.0-0.3$ \\
\hline Albumin (mg/dL) & 3.4 & - & 2.6 & 2.7 & 2.4 & $3.5-5.3$ \\
\hline $\begin{array}{l}\text { Promthrombin time } \\
\text { (sec) }\end{array}$ & - & - & - & 150 & 25 & $11-13$ \\
\hline $\mathrm{aPTT}(\mathrm{sec})$ & - & - & - & 95 & 65 & $24-35.5$ \\
\hline
\end{tabular}

Abbreviations: BUN, blood urea nitrogen; AST, aspartate transaminase; ALT, alanine transaminase; CRP, C-reactive protein; aPTT, activated partial thromboplastin time.
이 정상 소견이었고 혈액 배양검사에서 균은 동정되지 않았다. 뇌척 수액 분석검사는 정상, 세균 배양검사는 음성이었다. 입원 4일째, 체 온이 $37.9^{\circ} \mathrm{C}$ 측정되며 발열이 지속되었고 혈액검사상 아스파르테 이트아미노전달효소(aspartate transaminase, AST)는 1,072 U/L, 알 라닌아미노전달효소(alanine transaminase, ALT)는 $163 \mathrm{U} / \mathrm{L}$ 로 상승 되기 시작하였다. 입원 5일째부터 수유량이 $20 \mathrm{cc} / \mathrm{kg} / \mathrm{day}$ 로 현저히 줄어들어 면밀히 환아를 관찰하던 중 입원 6일째, 환아는 갑자기 청 색증과 기면을 보였다. 수축기 혈압 $50 \mathrm{~mm} \mathrm{Hg}$, 이완기 혈압 $30 \mathrm{~mm}$ $\mathrm{Hg}$ (평균 혈압 $37 \mathrm{~mm} \mathrm{Hg}$ )로 혈압이 저하되고 호흡부전을 보여 기 관 삽관 후 인공호흡기 치료를 시작하였다. 신체 진찰 시 간비대와 복수가 있었으며 피부병변은 보이지 않았다. 간기능 장애는 급격히 진행되어 AST는 6,367 U/L까지, ALT는 $738 \mathrm{U} / \mathrm{L}$ 까지 상승하였다. 프 로트롬빈 시간(prothrombin time, PT)과 활성화부분트롬보플라스 틴 시간(activated partial thromboplastin time)은 각각 150초와 95 초 로 연장되었고 international normalized ratio (INR)은 검출한계를 초 과하였다. 알부민(albumin)은 입원 5 일째 $2.6 \mathrm{mg} / \mathrm{dL}$ 로 감소하여 정 맥으로 알부민을 투여하였으나 입원 6 일째에도 $2.7 \mathrm{mg} / \mathrm{dL}$ 로 지속 적으로 감소된 소견을 보였다. 복부 초음파에서는 간비대, 복수, 담 낭벽의 부종이 관찰되었다. 만성적인 간질환이 없는 환아에게서 2 일 동안 급격한 간기능, 저하가 있고 혈액검사상 PT가 20초를 초과 하고 INR 2 를 초과하여 전격성 간부전에 합당한 소견이었다. 혈액 에서 A형/B형/C형 간염, 단순헤르페스 바이러스, 거대세포바이러 스, 풍진, 톡소플라즈마충에 대한 검사를 시행하였다. 입원 7일째, 환아의 혈액에서 시행한 단순헤르페스 바이러스 면역글로불린M (immunoglobulin M, IgM) 및 중합효소연쇄반응(polymerase chain reaction, $\mathrm{PCR}$ ) 검사에서 양성 소견이 확인되었다. 출혈의 위험성 때 문에 단순헤르페스 바이러스 PCR 검사를 위한 척수천자를 재시행 하지 않았으며 피부병변이 없어 피부에서 검사를 시행하지 않았다. 정맥으로 아시클로버 $(20 \mathrm{mg} / \mathrm{kg} /$ 회, 3 회/일) 투여를 시작하였고 이 후 28 일 동안 투여하였다. 집중적인 치료에도 불구하고 입원 7일째 저녁부터 환아의 상태는 악화되었다. 소변량은 $0.21 \mathrm{cc} / \mathrm{kg} / \mathrm{hr}$ 로 감 소하였고 혈액검사에서 혈액요소질소(blood urea nitrogen)는 55.2 $\mathrm{mg} / \mathrm{dL}$, 크레아티닌(creatinine)은 $2.0 \mathrm{mg} / \mathrm{dL}$ 로 상승하였다. 입원 8 일째, 입원 이후 지속되던 발열은 호전되었으나, 이뇨제 투여에 반 응하지 않는 급성신부전이 지속되어 혈중 칼륨 농도는 $7 \mathrm{mEq} / \mathrm{L}$ 까 지 상승하였다. 글루콘산칼슘(calcium gluconate), 탄산수소나트륨, 포도당과 인슐린을 투여하였으나 고칼륨혈증이 지속되어 입원 8 일 째 자정부터 복막투석을 시작하였다. 입원 9일째에 칼륨을 포함한 전해질은 정상화되었으나 소변량은 $1.0 \mathrm{cc} / \mathrm{kg} / \mathrm{hr}$, 혈액요소질소는 $54.8 \mathrm{mg} / \mathrm{dL}$, 크레아티닌은 $2.0 \mathrm{mg} / \mathrm{dL}$ 이었다. 입원 10일째 소변량이 증가하기 시작하여 저녁부터는 $2.5 \mathrm{cc} / \mathrm{kg} / \mathrm{hr}$ 이었으며, 혈액요소질 소는 $50.0 \mathrm{mg} / \mathrm{dL}$, 크레아티닌은 $1.9 \mathrm{mg} / \mathrm{dL}$ 로 감소하기 시작하였다. 4 일간의 복막 투석 후 입원 11 일째 소변량이 $2.7 \mathrm{cc} / \mathrm{kg} / \mathrm{hr}$ 로 증가하 
고 혈액요소질소는 $49.6 \mathrm{mg} / \mathrm{dL}$, 크레아티닌은 $1.7 \mathrm{mg} / \mathrm{dL}$ 로 감소하 여 투석을 종료하였다. 입원 18 일째에 환모의 혈액에서 시행한 단순 헤르페스 바이러스 $\operatorname{IgM}$ 과 $\operatorname{IgG}$ 항체검사 결과에서 양성 소견을 확인 하였다. 환아의 혈액에서 일주일 간격으로 단순헤르페스 바이러스 PCR 검사를 시행하여 입원 26일에 음성이 된 것을 확인하였다. 입원 51 일에 시행한 뇌 자기공명영상은 정상이었다. 환아는 입원 56 일에 간기능 및 신기능 정상화된 상태로 퇴원하였으며, 이후 생후 11 개월 까지 2 개월 간격으로 외래에서 추적관찰을 하였다. 환아는 신경학 적 증상 없이 정상 발달과 성장을 보였다. 상기 내용은 환아 부모에 게 사전 동의를 구한 후 보고한다.

고찰

신생아 단순헤르페스 바이러스 감염은 파종성으로 감염될 경우 가장 심각한 주산기 감염 중 하나로 감염의 대부분(85\%)은 출산 과 정에서 발생하고, $10 \%$ 는 출생 후에 발생하며 $5 \%$ 는 자궁 내에서 발 생한다. 단순헤르페스 바이러스에 감염된 신생아의 50\%-66\%는 파 종감염, $33 \%$ 는 중추신경계 감염, $20 \%$ 는 피부, 눈, 점막 질환을 보인 다 ${ }^{2)}$. 파종감염 환아에게 항바이러스제를 투여하지 않을 경우 $92 \%$, 치료할 경우 $86 \%$ 에서 1세 때 신경발달에 장애를 보인다 ${ }^{5)}$.

단순헤르페스 바이러스는 1형과 2형 두 가지가 있으며, 신생아 감 염은 대부분(70\%) 제2형 단순헤르페스 바이러스에 의한다 ${ }^{7)}$. 본원에 서는 단순헤르페스 바이러스 아형을 확인할 수 있는 PCR 검사가 불 가하여 본 환아에게 감염을 일으킨 아형을 확진하지는 못하였다. 생 후 3 일에 증상이 발생하였던 점을 고려하면 분만 과정 중 감염이 일 어났을 것으로 보여 제 2 형 단순헤르페스 바이러스에 의한 감염이었 을 가능성이 높다고 생각된다.

단순헤르페스 바이러스 감염에 의한 간염은 항바이러스 치료가 늦어질 경우 빠르게 악화되어 높은 치사율( $88 \%)$ 을 보인다 ${ }^{8)}$. 일반적 으로 3-7일 정도 잠복기를 거친 후 증상이 발현되며 3-10일 동안 발 열과 같은 비특이적인 증상을 보이다 간 괴사, 파종혈관내응고, 저 혈압으로 진행한다. 단순헤르페스 바이러스에 의한 간염이 의심되 거나 확진되면 고용량 $(20 \mathrm{mg} / \mathrm{kg} / \mathrm{dose}, 8$ 시간마다) 아시클로버를 정 맥으로 21 일 이상 투여하는 것이 권장되며 발병 48시간 이내에 투여 하는 것이 예후에 중요한 것으로 알려져 있다 ${ }^{9}$.

초기 증상이 비특이적이기에 진단과 치료가 늦어지기 쉬워 본 증 례에서도 입원 7일째에 혈액검사에서 단순헤르페스 바이러스 IgM 및 PCR 양성 검사결과를 확인한 후에야 아시클로버 투여가 시작되 었다. 단순헤르페스 바이러스에 감염된 신생아 중 $40 \%$ 에서는 피부 병변이 없고 ${ }^{10,11)}$, 산모의 단순헤르페스 바이러스 선별 검사 당시 혈 청학적 검사가 음성인 경우가 많기에 ${ }^{12)}$ 이 진단을 내리기 위해 피부 병변의 유무나 산모의 과거력에 의존해서는 안 된다.
발열이 있는 신생아에서 단순헤르페스 바이러스 감염을 감별 진 단으로 반드시 고려해야 하지만 모든 환아에게 일상적으로 항바이 러스제를 투여하는 것은 권고하지 않고 있다. 아시클로버의 경험적 투여를 시작해야 하는 적응증에 대한 표준화된 기준은 아직 정립된 것이 없지만, 피부 또는 점막 병변을 가진 환아가 급속한 증상 악화 나 다장기 기능 부전을 보일 경우 바이러스에 대한 검사결과가 나오 기 전이라도 항바이러스제 투여를 고려해볼 수 있겠다 ${ }^{5)}$. 또한 발열 과 함께 혈액검사상 급격한 간효소의 상승이 동반될 시 단순헤르페 스 바이러스에 의한 간염을 의심해봐야 한다 ${ }^{13)}$.

파종성 단순헤르페스 바이러스 감염에 의한 전격성 간부전의 생 존 사례는 드물게 보고 된다 ${ }^{6,14,15)}$. 이는 매우 빠르게 진행하는 임상 경과로 인해 이식 전 환자가 사망하기 때문이다. 특히 AST가 1,000 $\mathrm{U} / \mathrm{L}$ 이상인 경우는 매우 빠르게 사망한다 ${ }^{7,16)}$. 본 환아는 AST가 6,367 U/L까지 상승하였으나 항바이러스제와 복막투석만으로 중증 상태에서 호전되어 이식 없이도 생존하였다.

저자들은 단순헤르페스 바이러스 감염으로 인한 전격성 간부전 과 신부전 발생 후 이식 없이 약물과 투석을 통한 내과적 치료만으로 생존한 사례를 경험하였기에 이를 보고한다.

\section{ARTICLE INFORMATION}

\section{Ethical statement}

Informed consent was obtained from patient's parents. This study is approved from Institutional Review Board of Ajou University Hospital (AJIRB-MED-EXP-19-003).

\section{Conflicts of interest}

No potential conflict of interest relevant to this article was reported.

\section{Author contributions}

Conception or design: S.C., J.H.L.

Acquisition, analysis, or interpretation of data: S.C., M.S.P.

Drafting the work or revising: S.C., J.H.L.

Final approval of the manuscript: J.H.L.

\section{ORCID}

Seonghye Choi https://orcid.org/0000-0002-0680-8364

Jang Hoon Lee https://orcid.org/0000-0003-4765-9948

\section{Acknowledgments}

None 


\section{REFERENCES}

1. Looker KJ, Magaret AS, May MT, Turner KME, Vickerman P, Newman LM, et al. First estimates of the global and regional incidence of neonatal herpes infection. Lancet Glob Health 2017;5:e300-9.

2. Kimberlin DW. Herpes simplex virus infections of the newborn. Semin Perinatol 2007;31:19-25.

3. Corey L, Wald A. Maternal and neonatal herpes simplex virus infections. N Engl J Med 2009;361:1376-85.

4. Thompson C, Whitley R. Neonatal herpes simplex virus infections: where are we now? Adv Exp Med Biol 2011;697:221-30.

5. Abuhasna SD, Shihab ZM, Al Niyadi SM, Tatari HM, Al Jundi $\mathrm{AH}$, Atwa KH. Neonatal herpes simplex fulminant hepatitis successfully treated with acyclovir. J Clin Neonatol 2012;1:87-90.

6. Egawa H, Inomata Y, Nakayama S, Matsui A, Yamabe H, Uemoto $\mathrm{S}$, et al. Fulminant hepatic failure secondary to herpes simplex virus infection in a neonate: a case report of successful treatment with liver transplantation and perioperative acyclovir. Liver Transpl Surg 1998;4:513-5.

7. White JC, Magee SR. Neonatal herpes infection: case report and discussion. J Am Board Fam Med 2011;24:758-62.

8. Norvell JP, Blei AT, Jovanovic BD, Levitsky J. Herpes simplex virus hepatitis: an analysis of the published literature and institutional cases. Liver Transpl 2007;13:1428-34.

9. Cook G, Patel S, Williams R, Hodge J, Ingram W, Gayed R. Severe coagulopathy secondary to fulminant herpes simplex virus hepatitis in a severely burned patient: a case report and review of the literature. J Burn Care Res 2018;39:1071-6.

10. Arvin AM, Johnson RT, Whitley RT, Nelson JD, McCracken GH Jr. Consensus: management of the patient with herpes simplex encephalitis. Pediatr Infect Dis J 1987;6:2-5.

11. Koskiniemi M, Happonen JM, Jarvenpaa AL, Pettay O, Vaheri A. Neonatal herpes simplex virus infection: a report of 43 patients. Pediatr Infect Dis J 1989;8:30-5.

12. Guirguis-Blake J. Screening for genital herpes. Am Fam Phy sician 2005;72:135-6.

13. Ichai P, Roque Afonso AM, Sebagh M, Gonzalez ME, Codes L, Azoulay D, et al. Herpes simplex virus-associated acute liver failure: a difficult diagnosis with a poor prognosis. Liver Transpl 2005;11:1550-5.

14. Verma A, Dhawan A, Zuckerman M, Hadzic N, Baker AJ, MieliVergani $G$. Neonatal herpes simplex virus infection presenting as acute liver failure: prevalent role of herpes simplex virus type I. J Pediatr Gastroenterol Nutr 2006;42:282-6.

15. Twagira M, Hadzic N, Smith M, Ramaswamy M, Verma A, Dhawan A, et al. Disseminated neonatal herpes simplex virus (HSV) type 2 infection diagnosed by HSV DNA detection in blood and successfully managed by liver transplantation. Eur J Pediatr 2004;163:166-9.

16. Englund JA, Fletcher CV, Balfour HH Jr. Acyclovir therapy in neonates. J Pediatr 1991;119(1 Pt 1):129-35. 